\title{
Using E-learning System in Jordanian Universities during the COVID-19 Pandemic: Benefits and Challenges
}

\author{
Ahmad Abu-Al-Aish ${ }^{1}$ \\ ${ }^{1}$ Faculty of Computer Science and Information Technology, Department of Computer Science, Jerash University, \\ Jerash, Jordan \\ Correspondence: Ahmad Abu-Al-Aish, Faculty of Computer Science and Information Technology, Department \\ of Computer Science, Jerash University, Jerash, Jordan.
}

Received: May 21, 2021

doi:10.5539/cis.v14n3p49
Accepted: June 21, 2021

Online Published: July 5, 2021

URL: https://doi.org/10.5539/cis.v14n3p49

\begin{abstract}
During the Coronavirus Disease 2019 (COVID-19) pandemic and the national lockdowns implemented in countries around the world, many universities worldwide made the transition from face-to-face delivery to online learning using e-learning systems. However, the successful transition from traditional class-based learning to online learning depends greatly on understanding the challenges related to the implementation and use of e-learning systems, as well as the technical and management factors that need to be enhanced. This study aimed to investigate the challenges related to the use of e-learning systems in Jordanian universities and to explore the technical and management aspects that impacted the successful implementation and use of e-learning systems during COVID-19. To achieve the study objectives, a questionnaire was developed by the researcher and distributed online to lecturers working at Jordanian universities. A total of 184 lecturers participated in the study. Based on the findings, the study provides recommendations which will help higher education policy makers, university management teams, and software developers build strategies to ensure the successful implementation and use of e-learning systems during the COVID-19 pandemic.
\end{abstract}

Keywords: e-learning system, distance learning, COVID-19, online learning, challenges of e-learning, technical and management aspects

\section{Introduction}

The rapid spread of COVID-19 at the beginning of the year 2020 greatly impacted countries worldwide and forced many governments to implement national lockdowns, impacting economic, education, and tourism sectors worldwide. As a result, many schools and universities around the globe were forced to close down in order to prevent the spread of the highly infectious disease and protect students, teachers, and academic staff. Approximately 120 countries stopped face-to-face traditional learning, and a billion students worldwide have been affected by COVID-19 (Shahzad et al., 2020). In response to the outbreak, educational institutes made the transition from traditional face-to-face or blended-learning delivery methods to distance learning. Many universities started to offer their courses through online portals using digital video conferencing platforms like Zoom, Google Classroom, and Webex Blackboard (Shahzad et al., 2020).

The transition to online learning has posed many challenged to educational institutes around the globe (Dhawan, 2020). In Jordan, the decision to terminate campus-based delivery in universities and transition to distance learning was made by the Jordanian Ministry of Higher Education in the second semester of 2020. This came as a surprise for many lecturers and students, as university education in Jordan is usually mainly classroom-based. Although most Jordanian universities were already utilizing blended-learning methods using e-learning systems, the transition from traditional to online learning was not straightforward and came with many challenges (Bataineh et al., 2021).

This study is trying to investigate the challenges that face Jordanian universities in implementation and use of e-learning system During COVID-19 and to explore the technical and management aspects that need to be boosted. The current study aims to answer the following questions:

1. What are the benefits of using e-learning systems during the COVID-19 pandemic?

2. What were the efforts made by Jordanian universities to ensure the successful use of e-learning systems during 
the COVID-19 pandemic?

3. What were the challenges related to the successful implementation and use of e-learning systems in Jordanian universities during the COVID-19 pandemic?

4. What were the technical and management aspects that impacted the successful implementation and use of e-learning systems in Jordanian universities during the COVID-19 pandemic?

The rest of the paper is organized as follows: the following section presents a review of the literature related to the use of e-learning in higher education and its associated challenges, followed by an explanation of the research methodology, sampling method, and instrument. Then, the results are presented and the findings discussed, and finally, the study conclusion and recommendations for future research are presented.

\section{Related Work}

\subsection{E-learning (Online Learning)}

The rapid developments in the field of information and communication technology (ICT) have changed the style of teaching and learning, especially in higher education institutes. It is often nowadays that we hear expressions such as 'distance learning', 'online learning', 'web-based learning', and 'blended learning', all of which refer to some form of the utilization of the computer and the internet in teaching and learning (Dhawan, 2020). The use of technology in higher education can facilitate learning anytime and anywhere, providing students with engaging learning materials and allowing teachers to share learning content in all formats (Word documents, slideshows, PDFs, and videos), prepare and deliver lessons, and evaluate students (Bataineh et al., 2021; Raheem \& Khan, 2020). Therefore, e-learning can be a tool for making the teaching and learning process more student-centered, flexible, and inventive (Dhawan, 2020).

The term e-learning is defined as the use of computer tools and the internet for teaching and learning (Hong et al. 2017; Aljawarneh, 2020). Dhawan (2020) defined e-learning as a tool for learning in synchronous or asynchronous environments using technology devices connected to the internet, such as computers, laptops, and smart phones. In the synchronous case, the learning process is organized in a way which is similar to face-to-face classroom teaching, whereby the students and the lecturer are engaged in a live lecture on a video conferencing platform. This allows for direct interaction between students and lecturers and enables lecturers to offer instant feedback. Meanwhile, in the asynchronous case, the learning process is organized in a way which is different to face-to-face classroom teaching, whereby learning content is prepared by lecturers and made available on an e-learning system. In this form of e-learning, feedback can be provided through the e-learning system but is not instant (Dhawan, 2020; Jethro et al., 2012; Hrastinski, 2008).

Due to the increase in the use of e-learning worldwide, many researchers have investigated the advantages of the use of e-learning in higher education. E-learning has been found to be time- and money-saving for both part-time and full-time students, allowing many postgraduate students can register in online courses whilst also being employed (Shahzad et al., 2020). In addition, e-learning as a technological tool can be easily accessed from urban or rural areas and can offer students a flexible mode of study. Furthermore, the face-to-face delivery of lectures blended with online delivery using new technological tools can increase students' motivation and efforts to learn (Dhawan, 2020; Traxler, 2018).

On the other hand, some researchers argue that the use of e-learning in higher education can pose many challenges for both lecturers and students (Kenan et al., 2013; Raspopovic, 2014; Tarus et al., 2015). Azhari \& Ming (2015) reported that the most commonly reported challenges related to the use of e-learning in Malaysian universities include poor internet speed, lecturers and students' lack of experience in using technology for learning, poor technical infrastructure and readiness of universities, poor quality learning content, and usability of the system and universities adoption.

Nowadays, the current e-learning systems used in higher education institutes depend on the use of learning strategies which integrate new technologies and applications in the learning process. Students can interact and communicate with each other and with their lecturers through a computer network that allows for collaborative learning in the form of group work. Collaboration, discussion, and communication between students, lecturers, and students and lecturers using multiple interaction tools facilitate the achievement of teaching and learning goals (Wang et al., 2005; EL-Mhouti et al., 2018). Figure 1 illustrated e-learning system trends. 


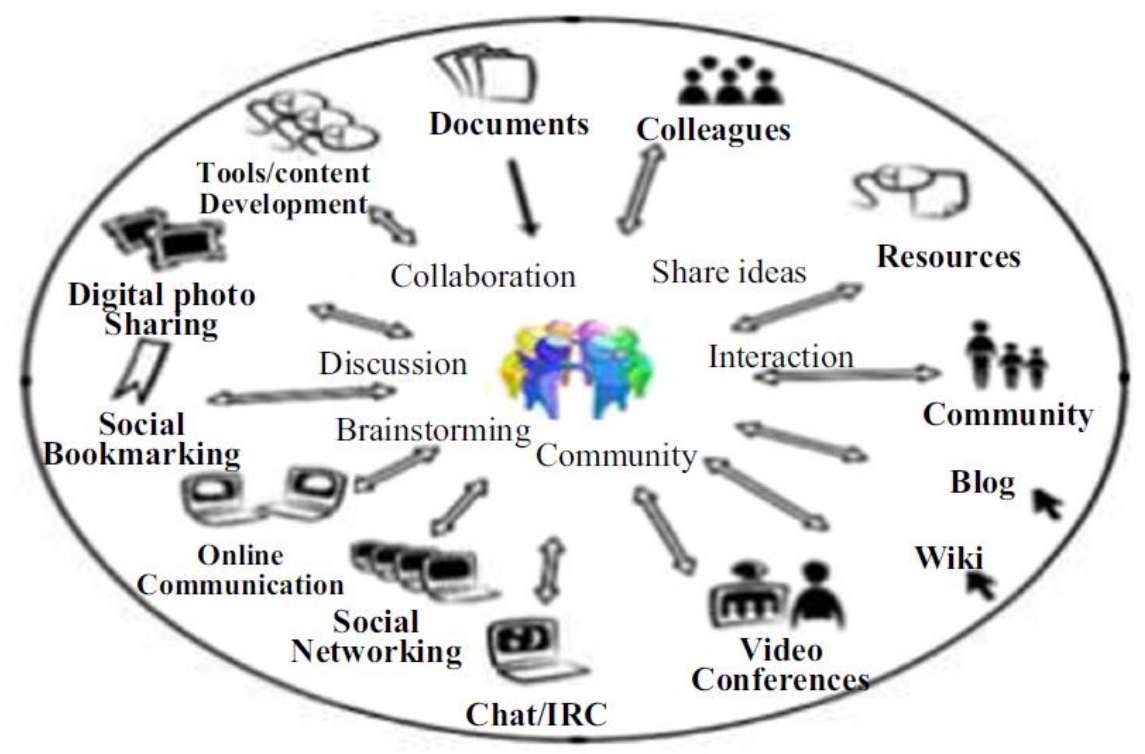

Figure 1. E-learning System Trends

\subsection{E-learning in Jordan}

The rapid developments in the field of ICT and the spread of the internet in Jordan since 2000 has made Jordan one of the leading countries in the Arab world in the ICT sector (Aljaraideh \& AlBataineh, 2019). Many universities in Jordan have started realizing the benefits of incorporating e-learning in their teaching and learning and now provide face-to-face teaching blended with e-learning. Universities such as University of Jordan, Jordan University of Science and Technology, Yarmouk University, and Jerash University use blended learning to deliver some of their courses, especially university and college requirement courses.

The barriers to e-learning in Jordanian universities have been explored in previous studies. Al-Adwan \& Smedley (2012) conducted a study to explore the capability of full-time students and lecturers in two Jordanian universities to engage with e-learning programs. The study also aimed to investigate the factors which impact the use of modern technology for learning. The results indicated that the technical infrastructure of universities needs to be updated, as this was the main barrier to the implementation of e-learning. It was also identified that students need to improve their technical skills in order to benefit further from this method of learning. In addition, it was identified that students and lecturers need to be provided with sufficient support and training in order to be able to use e-learning.

In a similar study, Aljaraideh \& AlBataineh (2019) examined the obstacles that prevent students in Jordanian universities from utilizing online leaning in their studies. The results showed that the infrastructure of universities in terms of the e-learning systems available to be the main barrier to the use of online learning. Furthermore, the results indicated that female students faced greater obstacles which hindered them from using online learning than did male students. The researchers suggested that raising students' awareness about the benefits of online learning, providing lecturers with sufficient training, and increasing expenditure on updating the technical infrastructure and modern e-learning tools used would promote the use of online learning in Jordanian universities.

Fayyoumi et al. (2015) identified six factors which may impact the spread of e-learning: society, culture, instructors, students, courses, and infrastructure. Almaiah et al. (2020) classified the challenges related to the implementation of e-learning systems into four categories: technological challenges, cultural challenges, individual challenges, and course challenges. These challenges differ from one country to another depending on cultural factors, the educational institutes, and e-learning context. In developing countries, the most common challenges related to the adoption of e-learning systems are poor network coverage, lack of ICT experience, and shortage of e-content (Aung \& Khaing, 2015).

Al-Shboul et al. (2013) suggested several points which should be taken into consideration for the successful implementation of e-learning in Jordanian universities. These points are summarized as follows: 
- Suitable technical infrastructure (hardware and software) should be made available.

- University decision makers should provide efficient choices regarding the internal software utilized for e-learning.

- Training courses related to the use of e-learning platforms and tools should be provided for lecturers, students, and staff.

- All users involved in the e-learning process should have easy access to the digital contents and learning tools.

Maabreh \& Hanandeh (2015) investigated students and lecturers' satisfaction and their degree of confidence towards e-learning services in higher education institutes in Jordan. The results revealed that there is a relationship between the e-learning services provided and its impact on students' learning the researchers suggested that universities need to develop their technical infrastructures and provide training courses to ensure the successful integration of technology in higher education in Jordan.

Similar to other developing countries, the aforementioned challenges make the implementation and use of e-learning systems in higher education institutes in Jordan difficult (Al-Khasawneh \& Obeidallah, 2019; Almaiah \& Al Mulhem, 2019). These challenges may be exacerbated in circumstances such as the COVID-19 pandemic. Therefore, there is a need for empirical research which investigates the challenges related to the implementation and use of e-learning systems in Jordanian universities during the COVID-19 pandemic.

It is worth mentioning that prior to the COVID-19 pandemic; the use of e-learning technology in Jordanian universities was restricted to blended learning courses and that there were no courses provided completely online. Hence, Jordanian universities were not fully prepared to depend completely on e-learning, due to several barriers and the lack of strong technological infrastructure. However, the outbreak of COVID-19 and the national lockdown implemented forced Jordanian universities to depend completely on e-learning as their only form of delivery and as the only choice for the continuity of teaching and learning.

\section{Research Methodology}

\subsection{Participants}

The participants of this study are Jordanian university lecturers working in public or private universities in Jordan. A total of 184 lecturers agreed to participate and completed the online questionnaire.

\subsection{Research Instrument}

A questionnaire was designed by the researcher in order to answer the research questions. The questionnaire was evaluated by a team of experts in e-learning and educational technology. The first section of the questionnaire included general questions about the lecturers (i.e. gender, academic rank, academic experience, e-learning experience, e-learning application used in teaching, and university type (i.e. public or private). The second section included twenty-three items scored on a 5-point Likert scale ranging from 1 (strongly disagree) to 5 (strongly agree). Finally, at the end of the questionnaire, there were two open-ended questions which gave the respondents a free space to express their opinions regarding the challenges related to e-learning in Jordanian universities and to suggest some technical and management aspects which should be improved. The participants' answers to the open-ended questions were analyzed using thematic analysis. The researcher used the following steps to conduct the thematic analysis: familiarization with datasets, generating initial codes, searching for themes, reviewing and naming themes, and presenting the final report (Silverman, 2011).

\subsection{Procedure}

To collect the data for this study, an online questionnaire was developed during the first semester of the academic year 2020/2021 (i.e. during the COVID-19 pandemic). Universities in Jordan were closed and had started fully using e-learning since $15^{\text {th }}$ March 2020 . The questionnaire link was sent to the lecturers by email and through social media applications (i.e. Facebook and WhatsApp). The required completion time for the questionnaire was approximately 7-10 minutes. The participants were informed that the data collected and their details would be kept anonymous and that they could withdraw from the study at any time. 


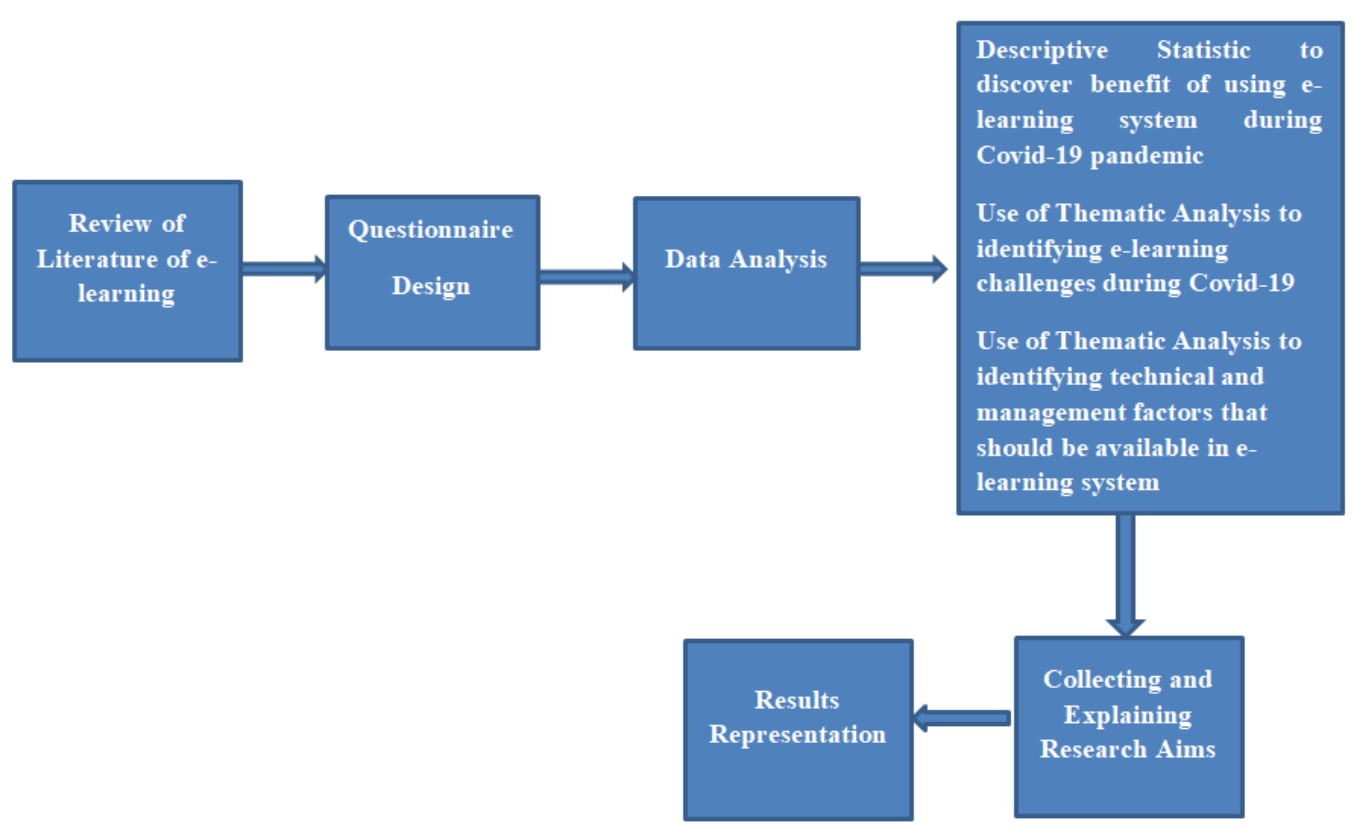

Figure 2. Research methodology framework

\section{Results and Discussion}

The data obtained from the participants were coded and analyzed using the Statistical Package for the Social Sciences (SPSS) version 16.0.

\subsection{Demographic Characteristics of the Participants}

The questionnaire included six questions related to the demographic characteristics of the participating lecturers. These characteristics were gender, academic rank, academic experience, e-learning experience, e-learning applications used in teaching, and the type of university (i.e. public or private). The demographic characteristics of the participants, along with the percentages, are displayed in Table 1.

Of the total participants, $61.4 \%$ were male and $38.6 \%$ were female. As with regards to academic rank, $17.9 \%$ of the participants were lecturers, $46.2 \%$ were assistant professors, $24.5 \%$ were associate professors, and $11.4 \%$ were full professors. As for academic experience, $14.1 \%$ of the participants had 1-3 years of experience, $33.7 \%$ had $4-6$ years, $25.0 \%$ had $7-9$ years, and $27.2 \%$ had 10 or more years.

In total, $55.4 \%$ of the participants had 1 year of e-learning experience, whilst $44.6 \%$ had more than 2 years. As with regards to the e-learning application used to teach students during the COVID-19 pandemic, over half the participants (68.5\%) used Zoom, 12.5\% used Blackboard, $10.3 \%$ used Microsoft Teams, and $8.7 \%$ used Google Classroom. Finally, half of the participants (50.0\%) were working in public universities, and the other half were working in private universities. 
Table 1. Demographic characteristics of the participants (with percentages)

\begin{tabular}{|c|c|c|c|}
\hline Demographic & Frequency & Percentage & Cumulative percentage \\
\hline \multicolumn{4}{|l|}{ Gender } \\
\hline Female & 71 & $38 . .6$ & 38.6 \\
\hline Male & 113 & 61.4 & 100 \\
\hline \multicolumn{4}{|l|}{ Academic Rank } \\
\hline Lecturer & 33 & 17.9 & 17.9 \\
\hline Assistant Professor & 85 & 46.2 & 64.1 \\
\hline Associate Professor & 45 & 24.5 & 88.6 \\
\hline Full Professor & 21 & 11.4 & 100.0 \\
\hline \multicolumn{4}{|l|}{ Academic Experience } \\
\hline 1-3 years & 26 & 14.1 & 14.1 \\
\hline 4-6 years & 62 & 33.7 & 47.8 \\
\hline 7-9 Years & 46 & 25.0 & $72 . .8$ \\
\hline 10 years or more & 50 & 27.2 & 100.0 \\
\hline \multicolumn{4}{|l|}{ E-learning Experience } \\
\hline 1 year & 102 & 55.4 & 55.4 \\
\hline 2 years & 15 & 8.2 & 63.6 \\
\hline 3 years & 24 & 13.0 & 76.6 \\
\hline 4 years or more & 43 & 23.4 & 100.0 \\
\hline \multicolumn{4}{|l|}{ E-learning application } \\
\hline Zoom & 126 & 68.5 & 68.5 \\
\hline Google classroom & 16 & 8.7 & 77.2 \\
\hline Microsoft Teams & 19 & 10.3 & 87.5 \\
\hline Blackboard & 23 & 12.5 & 100.0 \\
\hline \multicolumn{4}{|l|}{ University } \\
\hline Public & 92 & 50.0 & 50.0 \\
\hline Private & 92 & 50.0 & 100.0 \\
\hline
\end{tabular}

\subsection{Quantitative Analysis}

The questionnaire included three sections. The first two sections were related to the benefits of using e-learning systems during the COVID-19 pandemic and covered two aspects: benefit for students and benefit for lecturers. The third section was related to the efforts made by universities to ensure the successful use of e-learning systems. Each section included five to nine questions. The Cronbach's alpha test was conducted to examine the reliability of the instrument. A Cronbach's alpha value between 0.70 and 0.80 is regarded as acceptable, and a value between 0.80 and 0.90 is regarded as very good (Sekaran, 2003). The Cronbach's alpha values for the questionnaire sections ranged between 0.7 and 0.85 , indicating that the questions were consistent and free of errors. Table 2 presents the main sections, the questions in each section, and the means and Cronbach's alpha values for each section.

\subsection{Benefit of E-learning for Students}

Question 1.1 asked about whether e-learning had improved students' self-learning. The mean score for this question was 3.97, which is very close to 4 and indicates that the participating lecturers do believe e-learning to have improved students' self-learning. The second question (1.2) was related to the contents of e-learning. The mean score for this question was 4.11, which falls between 'agree' and 'strongly agree'. The third question (1.3), which asked whether the e-learning system was easy to use for students, had a mean score of 3.66, which is slightly more positive than neutral. Question 1.4 examined if the e-learning system provided students and lecturers with communication tools; the mean score was 3.68, which is a positive response. Question 1.5 asked if the e-learning system allowed lecturers to provide students with direct feedback. The mean score was 3.7, which is close to 'agree'. The sixth question (1.6), which asked if e-learning allowed students to study at any time during the week, had a mean score of 3.78, which is close to 'agree'. The section had an overall mean score of 3.82 , which is close to 4 and indicates that the participants agreed that their students had benefited from the use of e-learning systems.

\subsection{Benefit of E-learning for Lecturers}

Question 1.7 asked if the participants had the basic skills needed to use e-learning systems. The main score for this question was 4.13, which falls between 'agree' and 'strongly agree' and indicates that the lecturers believed they were able to use e-learning systems without difficulty. Question 1.8 investigated the suitability of e-learning for teaching theoretical courses. The mean score for this question was 4.07 , which is very close to 'agree' and 
indicates that the participating lecturers believed e-learning to be suitable for teaching theoretical courses. Question 1.9 asked the respondents if they believed e-learning to be suitable for teaching lab courses. The mean score was 2.8 , which falls between 'disagree' and 'neutral' and indicates that the participants did not believe e-learning to be suitable for teaching lab courses. Question 1.10 asked the respondents if they believed e-learning to be suitable for teaching training courses, and similar to question 1.9, the mean score was 2.76. Question 1.11 asked the respondents if teaching using e-learning systems required less effort than traditional classroom-based teaching. The mean score was 2.34 , which falls between 'disagree' and 'neutral' and indicates that the participating lecturers did not believe e-learning to require less effort than traditional classroom-based teaching. Question 1.12, which asked the respondents if they believed that e-learning systems could be used to evaluate students' performance in a fair manner, had a mean score of 3.16, which is close to 'neutral'. Question 1.13 asked if the use of e-learning allowed lecturers to monitor students' attendance during the COVID-19 pandemic. The mean score was 4.08 , which is close to 4 and indicates that the participants agreed that they had been able to monitor their students' attendance. Question 1.14 asked the respondents if they believed e-learning should be blended with traditional learning after COVID-19. The mean score for this question was 4.3, which falls between 'agree' and 'strongly agree'. The final question in this section (1.15) asked the respondents if they believed their universities to be capable of fully depending on e-learning for teaching courses after COVID-19. The mean score was 3.7, which is close to 4 and which indicates that the participants agreed with the statement. The overall mean score for this section was 3.45 , which falls between 'neutral' and 'agree' and which indicates that the participants had neutral thoughts regarding the benefit of e-learning for lecturers.

\subsection{Universities' Efforts to Ensure the Successful Use of E-learning Systems During the COVID-19 Pandemic}

Question 2.1, which asked the respondents if their university had provided students with technical guidelines on how to use the e-learning system, had a mean score of 4.15, indicating that the participants agreed. Question 2.2 asked the respondents if their universities had provided lecturers with training workshops on how to use the e-learning system and had a mean score of 3.92, which is very close to 'agree'. Question 2.3 asked the respondents if their universities had provided lecturers with technical support while using the e-learning system and had a mean score of 3.98, which is similar to question 2.2. Question 2.4 asked the respondents if their universities had kept the e-learning systems secured to protect users' privacy and learning content. The mean score was 4.52, which falls between 4 ('agree') and 5 ('strongly agree'). The final question (2.5) asked the respondents if their universities had worked hard to ensure the sustainability and quality of e-learning. The overall mean score for this section was 4.13 , which falls between 4 ('agree') and 5 ('strongly agree').

Table 2. Questionnaire sections, survey questions, mean scores, and Cronbach's alphas

\begin{tabular}{|c|c|c|c|c|c|c|c|}
\hline Questions & $\begin{array}{l}\text { Strongly } \\
\text { Disagree }\end{array}$ & Disagree & Neutral & Agree & $\begin{array}{l}\text { Strongly } \\
\text { Agree }\end{array}$ & Mean & $\begin{array}{l}\text { Cronbach } \\
\text { alpha }\end{array}$ \\
\hline \multicolumn{8}{|c|}{ Benefit of using e-learning systems for students $(\mathrm{M}=3.82)$} \\
\hline $\begin{array}{l}\text { 1.1. E-learning has improved students' } \\
\text { self-learning at your university }\end{array}$ & $0 \%$ & $0.5 \%$ & $3.3 \%$ & $94.6 \%$ & $1.6 \%$ & 3.97 & \multirow{6}{*}{$\mathbf{0 . 8 0}$} \\
\hline $\begin{array}{l}\text { 1.2. E-learning contents } \begin{array}{l}\text { include course } \\
\text { description, assignments, quizzes, video } \\
\text { links, and multimedia }\end{array} \\
\end{array}$ & $1.6 \%$ & $3.3 \%$ & $11.4 \%$ & $49.5 \%$ & $34.2 \%$ & 4.11 & \\
\hline $\begin{array}{l}\text { 1.3. It is easy for students to keep up with } \\
\text { the e-learning system (i.e. attend online } \\
\text { lectures, attend online exams, and upload } \\
\text { assignments) }\end{array}$ & $1.6 \%$ & $8.7 \%$ & $27.2 \%$ & $47.3 \%$ & $15.2 \%$ & 3.66 & \\
\hline $\begin{array}{l}\text { 1.4. E-learning provides students } \\
\text { lecturers with } \begin{array}{c}\text { and } \\
\text { synchronous }\end{array} \\
\text { asynchronous communication tools }\end{array}$ & $0.5 \%$ & $12.5 \%$ & $25.5 \%$ & $40.8 \%$ & $20.7 \%$ & 3.68 & \\
\hline $\begin{array}{l}\text { 1.5. E-learning provides students with direct } \\
\text { and quick instructor feedback }\end{array}$ & $0 \%$ & $13.0 \%$ & $16.8 \%$ & $56.0 \%$ & $14.1 \%$ & 3.71 & \\
\hline $\begin{array}{l}\text { 1.6. E-learning provides students with } \\
\text { interactive mobile learning which allows } \\
\text { them to study anytime during the week }\end{array}$ & $0 \%$ & $4.9 \%$ & $26.6 \%$ & $53.8 \%$ & $14.7 \%$ & 3.78 & \\
\hline \multicolumn{8}{|c|}{ Benefit of using e-learning systems for lecturers $(\mathrm{M}=3.45)$} \\
\hline $\begin{array}{l}\text { 1.7. Do you think that you have the basic } \\
\text { skills for utilizing e-learning tools }\end{array}$ & $0 \%$ & $2.7 \%$ & $14.7 \%$ & $49.5 \%$ & $33.2 \%$ & 4.13 & \\
\hline $\begin{array}{l}\text { 1.8. E-learning at your university is suitable } \\
\text { for teaching theoretical courses }\end{array}$ & $2.2 \%$ & $4.3 \%$ & $9.2 \%$ & $52.7 \%$ & $31.5 \%$ & 4.07 & \\
\hline 1.9. E-learning at your university is suitable & $1.6 \%$ & $33.2 \%$ & $48.9 \%$ & $15.8 \%$ & $0.5 \%$ & 2.8 & \\
\hline
\end{tabular}




\begin{tabular}{|c|c|c|c|c|c|c|c|}
\hline \multicolumn{7}{|l|}{ for teaching lab courses } & \multirow{7}{*}{0.70} \\
\hline $\begin{array}{l}\text { 1.10. E-learning at your university is suitable } \\
\text { for teaching training courses }\end{array}$ & $2.2 \%$ & $28.8 \%$ & $60.3 \%$ & $8.7 \%$ & $0 \%$ & 2.76 & \\
\hline $\begin{array}{l}\text { 1.11. Teaching using e-learning requires less } \\
\text { effort than traditional teaching }\end{array}$ & $21.2 \%$ & $42.9 \%$ & $19.6 \%$ & $13.6 \%$ & $2.7 \%$ & 2.34 & \\
\hline $\begin{array}{l}\text { 1.12. E-learning allows lecturers to evaluate } \\
\text { students' performance during the COVID-19 } \\
\text { pandemic in a fair manner }\end{array}$ & $6.0 \%$ & $23.4 \%$ & $27.7 \%$ & $34.2 \%$ & $9.7 \%$ & 3.16 & \\
\hline $\begin{array}{l}\text { 1.13. E-learning allows lecturers to monitor } \\
\text { students' attendance during the COVID-19 } \\
\text { pandemic }\end{array}$ & $2.2 \%$ & $6.0 \%$ & $9.8 \%$ & $45.7 \%$ & $36.4 \%$ & 4.08 & \\
\hline $\begin{array}{l}\text { 1.14. Do you think that e-learning should be } \\
\text { blended with traditional learning after } \\
\text { COVID- 19? }\end{array}$ & $2.2 \%$ & $3.8 \%$ & $13.0 \%$ & $51.1 \%$ & $29.9 \%$ & 4.3 & \\
\hline $\begin{array}{l}\text { 1.15. Do you think that your university is } \\
\text { capable of fully depending on e-learning for } \\
\text { teaching theoretical courses after the } \\
\text { COVID-19 pandemic is over? }\end{array}$ & $4.9 \%$ & $15.2 \%$ & $11.4 \%$ & $41.8 \%$ & $26.6 \%$ & 3.7 & \\
\hline \multicolumn{8}{|c|}{$\begin{array}{l}\text { Universities' efforts to ensure the successful use of e-learning systems during the COVID-19 pandemic } \\
(\mathrm{M}=4.13)\end{array}$} \\
\hline $\begin{array}{l}\text { 2.1. Your university provided students with } \\
\text { technical guidelines on how to use the } \\
\text { e-learning system }\end{array}$ & $1.6 \%$ & $6.5 \%$ & $8.2 \%$ & $42.4 \%$ & $41.3 \%$ & 4.15 & \multirow{5}{*}{$\mathbf{0 . 8 5}$} \\
\hline $\begin{array}{l}\text { 2.2. Your university provided lecturers with } \\
\text { training workshops on how to use the } \\
\text { e-learning system }\end{array}$ & $3.8 \%$ & $9.2 \%$ & $10.9 \%$ & $42.9 \%$ & $33.2 \%$ & 3.92 & \\
\hline $\begin{array}{l}\text { 2.3. Your university provided lecturers with } \\
\text { technical support while using e-learning }\end{array}$ & $5.4 \%$ & $4.3 \%$ & $13.6 \%$ & $40.2 \%$ & $36.4 \%$ & 3.98 & \\
\hline $\begin{array}{l}\text { 2.4. Your university kept the e-learning } \\
\text { system secured to protect users' privacy and } \\
\text { learning content }\end{array}$ & $1.1 \%$ & $2.7 \%$ & $3.8 \%$ & $27.7 \%$ & $64.7 \%$ & 4.52 & \\
\hline $\begin{array}{l}\text { 2.5. Your university worked hard to ensure } \\
\text { e-learning quality and its sustainability }\end{array}$ & $2.2 \%$ & $4.3 \%$ & $15.2 \%$ & $40.8 \%$ & $37.5 \%$ & 4.07 & \\
\hline
\end{tabular}

\subsection{Open-ended Question Results}

The open-ended questions were aimed at exploring the main challenges related to the transition from classroom-based teaching to e-learning in Jordanian universities. To achieve this, the questionnaire included the open-ended question: What are the main challenges related to the implementation and use of e-learning systems during the COVID-19 pandemic? A total of 140 responses were obtained. The lecturers addressed the following challenges in their responses:

1. Lack of technical infrastructure (i.e. servers and e-learning platforms) in some universities was reported as being a challenge. One lecturer wrote: "the existing servers are not sturdy enough to handle the pressure of students and lecturers together". Another lecturer wrote: "university servers are inefficient for this style of learning". Furthermore, challenges related to the quality of the e-learning platforms used and the technical support provided by the universities was reported. One lecturer commented: "the technical infrastructure of universities, including the services available on the e-learning platforms and the technical support speed, is a challenge".

2. Poor internet connection, speed, and coverage were other reported challenges. Some lecturers mentioned "weak internet connection", "lack of internet coverage", and "frequent internet outages" as being barriers to the success of e-learning. One participant wrote that "poor internet connection and slow download speed reduced voice and image quality during online lectures and made it difficult for students to download videos".

3. Lack of student commitment to e-learning was also reported. Some lecturers wrote that "students were not very committed to attending e-learning lectures and uploading assignments". Other lecturers also mentioned that some students "lack interest", "lack engagement with e-learning", and "do not recognize the benefits of e-learning". From the lecturers' point of view, some students lacked interest and did not engage with the e-learning system. One lecturer wrote: "there are varying degrees of concern and interest among students to take matters seriously and with responsibility and commitment". Another lecturer commented: "It is not easy to get students interested in attending online lectures". 
4. Lack of technical experience among some lecturers and students in dealing with modern technologies and e-learning systems was another reported challenge, especially given that the decision to depend fully on e-learning systems during the COVID-19 pandemic had been sudden. Further, 77\% of the participating lecturers had 1-3 years of e-learning experience, which was reflected in their responses to this question. Their comments mentioned that "lecturers and students had not been prepared to transition fully to e-learning" and that "e-learning had appeared suddenly, with many students lacking the experience in using e-learning systems". Also, other lecturers commented that "some lecturers and students do not have sufficient experience in using new technologies in the process of teaching and learning" and that "the lecturers and students lacked the necessary skills for dealing with the requirements of e-learning". One participant wrote: "there is a lack of prior experience in using e-learning systems".

5. The lack of interaction between students and lecturers was another reported challenge. The lecturers highlighted that e-learning was causing a gap in interaction between students and lecturers. One lecturer commented: "students do not interact in the required and sufficient manner for the success of this form of learning". Another lecturer reported "limited interaction" as being a barrier, whilst another wrote: "it [e-learning] does not replace face-to-face interaction in any way". Another lecturer mentioned: "no tool can replace direct face-to-face interaction between lecturers and students". It was also reported that students did not interact with the e-learning system, as one lecturer wrote: "students' interaction with e-learning is not at the required level".

6. The unavailability of adequate multiple technical tools needed for obtaining successful learning outcomes was another reported barrier. One lecturer reported that "the unavailability of tools needed to meet the requirements of e-learning systems (i.e. computer services, internet packages)" was a barrier. Further, one lecturer mentioned that not all students had access to "computer devices and smart phones". In addition, it was reported that some students cannot afford to use e-learning. One lecturer wrote: "some students do not have laptops, smart phones, or even internet connection".

7- Cultural views towards e-learning and resistance among students and lecturers to shift from traditional learning to e-learning were also reported as being a barrier. Some lecturers highlighted that some students and lecturers could not accept the idea of transitioning to e-learning. Their comments revealed that there was a lack of "community acceptance" and "psychological acceptance among students and teachers". Also, one lecturer wrote: "there is resistance among some lecturers and students to switch from traditional learning to e-learning".

8. Another reported challenge was the difficulty in teaching practical, lab, and medical courses online. The majority of the lecturers reported that e-learning was not suitable for teaching practical courses which require lab work or training, such as medical or nursing courses. One lecturer wrote: "the main challenge in e-learning is teaching applied medical science courses and field training courses online". Another lecturer wrote: "teaching practical courses online is a challenge", whilst another lecturer wrote: "some subjects require practical teaching, which cannot be achieved electronically".

9. Another reported challenge was related to the evaluation of students' performance in a fair manner, which includes conducted and monitoring exams. The lecturers highlighted in their comments that "ensuring the smooth running of exams" and "conducting and monitoring exams" were challenges. Another lecturer wrote: "the way that exams are conducted may be unfair and inaccurate". Two participants suggested that "there is a need to find a tool which allows teachers to evaluate students and prevents students from cheating", and that "there is a need for applications which ensure exam quality".

The second open-ended question was aimed at encouraging the participating lecturers to suggest some technical and management aspects of e-learning which could be improved. The lecturers were asked: What are the technical and management aspects of e-learning systems that should be improved during the COVID-19 pandemic.

The participants' responses can be summarized as follows:

1. Universities should conduct training courses for lecturers and students to help them use e-learning platforms properly. One lecturer wrote that universities should "provide students and lecturers with training courses and workshops on how to use e-learning properly". Another lecturer mentioned: "faculty members should be trained on everything new related to using e-learning systems", and another mentioned the need to "increase training on how to use this new method of teaching and learning".

2. There is a need to improve the technical infrastructure in some Jordanian universities, which includes updating servers to ensure that they are sturdy enough to handle work pressure and the large number of users, improving e-learning platforms to allow for more interaction between users, and ensuring that no disconnections occur. One 
lecturer mentioned the need for "up-to-date servers and ensuring that no disconnections occur". Other lecturers mentioned the need to "provide lecturers with special programs that help them teach practical subjects". It was also mentioned that there is a need for e-learning systems to be monitored during rush hours in order to ensure that no technical problems occur. One lecturer commented that there is a need to "follow up the technical issues that may occur on the e-learning system during peak and pressure periods and ensure that there are no conflicts in the students' timetables". Another lecturer mentioned the need to "improve our universities' technical infrastructure to ensure that we are able to keep pace with the rapid changes in modern technology".

3. Students should be allowed to choose from different methods for communicating with their lecturers and should not be restricted to a specific e-learning platform. One participant highlighted the need to "use social media platforms such as WhatsApp and Facebook as communication tools in addition to the e-learning platform". Another respondent mentioned that "universities should not specify one application for communicating with students" and that "students should be made aware of the importance of communicating with their lecturers via any available application". Another lecturer added that "using WhatsApp or Facebook to create study groups and share educational videos is the simplest and easiest way".

4. Students should be provided with laptops and free internet bundles. Some respondents suggested that this was essential, as some students do not have laptops and others cannot afford to purchase internet bundles. One lecturer wrote: "universities should grant students free internet bundles", whilst another wrote: "universities should provide students with free internet bundles and a free laptop".

5. E-learning systems should be secured from cyber-attacks, as some respondents were concerned about the security aspects of the e-learning systems used. The lecturers mentioned the need to "create safe programs to protect the e-learning systems from being hacked", "enhance the security of e-learning systems to protect them from being hacked", and "protect the e-learning systems from cyber threats and attacks".

6. There is a need to ensure that all areas across the country have internet coverage, as some lecturers reported that some urban or desert areas in the country lack internet coverage. One participant mentioned the need to "ensure that there is suitable internet coverage in urban areas". Another respondent added that there is a need to "ensure the continuity of internet coverage and speed in order for e-learning systems to handle the pressure and the large number of users". Another participant reported the need to "connect lecturers and students to strong networks without frequent interruptions".

7. There is a need for a tool which enables lecturers to monitor and control students during exams. One lecturer wrote: "there is a need to establish an appropriate method of monitoring students during exams". Another participant suggested "monitoring students with cameras while teaching and during exams". Another lecturer explained that evaluating students in a fair manner required "adding a service that increases the efficiency of student evaluation, especially during exams".

Figure 3 presents the challenges related to e-learning and the technical and management aspects that require improvement. 


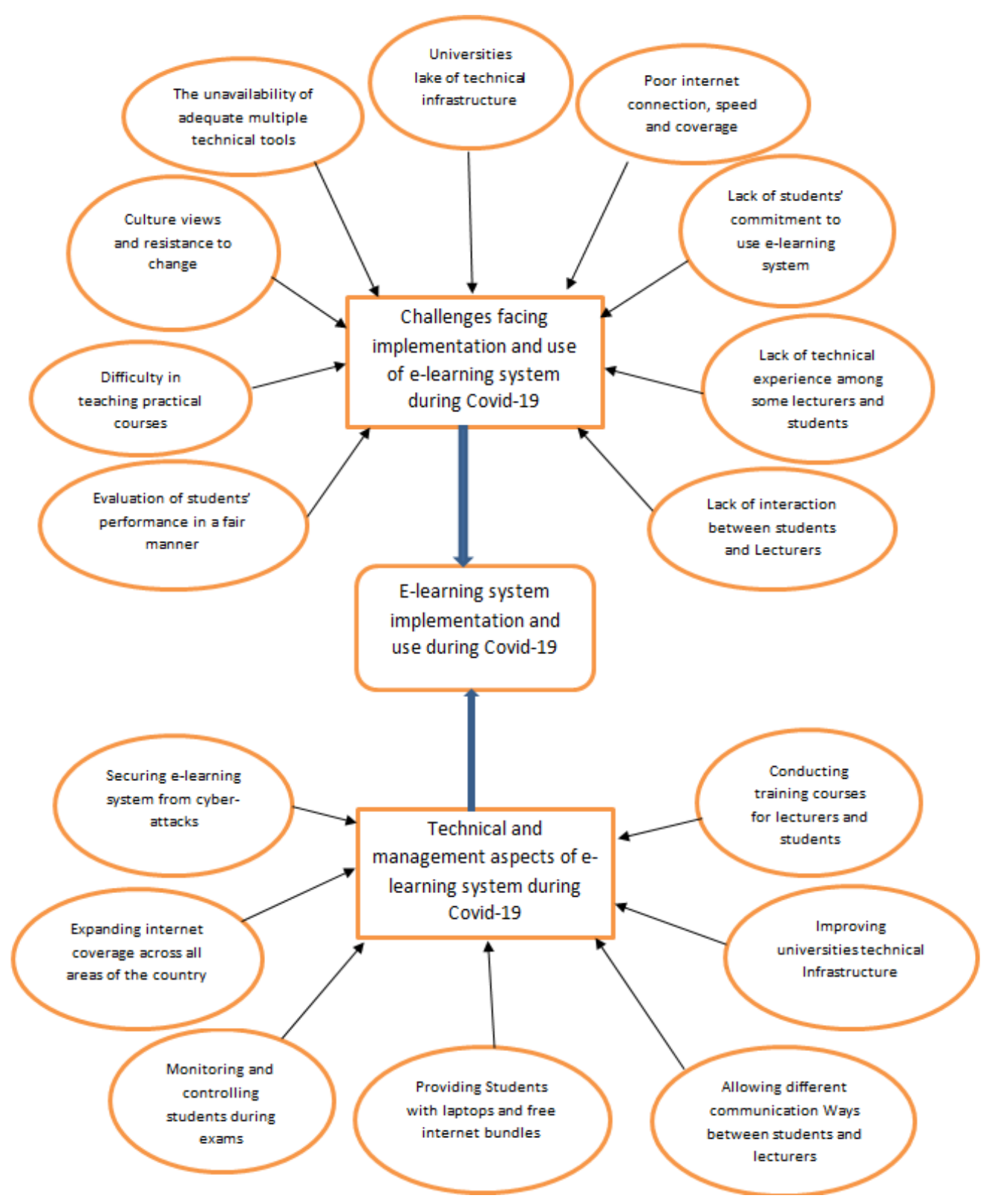

Figure 3. Framework of the challenges, technical and management aspects of e-learning system use during the COVID-19 pandemic

\section{Recommendations}

Based on the results, the researcher suggests the following recommendations:

- Universities should provide both students and lecturers, particularly those with less experience in e-learning, with continuous training courses on the use of e-learning systems. This is particularly important during the COVID-19 pandemic, as the transition to e-learning was sudden. Training will increase lecturers and students' knowledge and awareness of how to effectively use e-learning.

- University management teams should update the technical infrastructure (hardware and software) of their universities, which may include creating new servers, providing students with access to the internet, and creating e-learning applications. This will motivate lecturers and students to utilize e-learning in their teaching and learning effectively and will increase interaction between them. 
- Telecommunication companies should provide good internet coverage, high speed internet, and affordable internet bundles for students, as some students cannot afford to pay for internet bundles at their current cost.

- University management teams and technical support teams should find a new e-learning tool for evaluating students and monitoring them during exams in a fair manner during the COVID-19 pandemic.

- E-learning system developers need to develop e-learning programs that allow lecturers to deliver practical courses, especially in the fields of engineering and health sciences.

- E-learning system designers and developers need to ensure that their systems are protected against cyber threats and attacks.

- Universities should engage students in and increase their commitment to e-learning (i.e. attending online lecturers), as many students prefer face-to-face classroom-based teaching and enjoy campus life.

\section{Conclusion and Future Research}

Many lecturers and students in Jordanian universities had not been prepared for the sudden transition from traditional learning to online learning during the COVID-19 pandemic. Universities did not have sufficient time to prepare for this transition and ensure the availability of e-learning resources. Hence, there is a need to investigate the challenges related to the implementation and use of this form of learning and to explore the technical and management aspects related to e-learning that need to be enhanced.

The results of this study shed light on the challenges related to the implementation and use of e-learning systems in developing countries during the COVID-19 pandemic. The first and second research questions were addressed through the study survey. The participants agreed about the benefits of e-learning for both students and lecturers, and they also agreed that their universities were making several efforts to ensure the successful use of e-learning systems during the COVID-19 pandemic. The third and fourth research questions were addressed through the two open-ended questions included in the study survey. These questions were constructed around two points: (1) the challenges related to the implementation and use of e-learning systems during the COVID-19 pandemic, and 2) the technical and management aspects related to e-learning that should be enhanced to ensure successful teaching and learning outcomes.

Based on the findings, the main identified challenges related to e-learning in higher education institutes were: (1) lack of technical infrastructure in universities, (2) lack of technical experience among lecturers and students, (3) lack of interaction between lecturers and students, (4) lack of commitment to using e-learning systems among students, (5) poor internet connection and speed, (6) the unavailability of technical tools, (7) cultural views towards e-learning and resistance to change, (8) difficulty teaching practical courses online, and (9) difficulty ensuring the fair evaluation of students' performance. Universities should take these challenges into consideration in any future e-learning plans.

In addition, the participants suggested some technical and management aspects related to e-learning that need to be enhanced: (1) universities should provide training courses, (2) universities should improve their technical infrastructure, (3) universities should allow students and lecturers to choose from a variety of communication methods, (4) universities should provide students with free laptops and internet bundles, (5) universities should find a method of monitoring students during online exams, (6) telecommunication companies should ensure that all areas in the country have internet coverage, and (7) e-learning system developers should ensure that their systems are protected from cyber threats and attacks.

The present study provides a clear picture of the situation regarding the implementation and use of e-learning in developing countries like Jordan. The study findings can be of use for university management teams, education policy makers in the Ministry of Higher Education, and e-learning software developers. The findings of this study contribute to the literature by identifying new challenges and technical and management aspects related to e-learning that need to be enhanced. The results shed light on the need for guidelines aimed at ensuring the sustainability and effective implementation and use of e-learning systems in Jordanian universities both during and after the COVID-19 pandemic.

The results of this study provide preliminary data regarding the experiences of lecturers at higher education institutes in Jordan in transitioning from traditional learning to online learning and using e-learning systems during the COVID-19 pandemic. Many Jordanian universities have made the decision to adopt e-learning for the coming semesters. Thus, future research may investigate whether lecturers and students' e-learning experience has improved with time. 


\section{References}

Al-adwan, A., \& Smedley, J. (2012). Implementing e-learning in the Jordanian Higher Education System: Factors affecting impact. International Journal of Education and Development using Information and Communication Technology, 8(1), 121-135.

Aljaraideh, Y., \& Al Bataineh, K. (2019). Jordanian Students' Barriers of Utilizing Online Learning: A Survey Study. International Education Studies, 12(5), 99-109. https://doi.org/10.5539/ies.v12n5p99

Aljawarneh, S. A. (2020). Reviewing and exploring innovative ubiquitous learning tools in higher education', Journal of computing in higher education, 32(1), 57-73. https://doi.org/10.1007/s12528-019-09207-0

Al-Khasawneh, A. M., \& Obeidallah, R. (2019). E-Learning in the Hashemite University: Success Factors for Implementation in Jordan. In M. Habib (Ed.), Advanced Online Education and Training Technologies (pp. 135-145). IGI Global. https://doi.org/10.4018/978-1-5225-7010-3.ch008

Almaiah, M. A., \& Al Mulhem, A. (2019). Analysis of the essential factors affecting of intention to use of mobile learning applications: A comparison between universities adopters and non-adopters. Education and Information Technologies, 24(2), 1433-1468. https://doi.org/10.1007/s10639-018-9840-1

Almaiah, M. A., Al-Khasawneh, A., \& Althunibat, A. (2020). Exploring the critical challenges and factors influencing the E-learning system usage during COVID-19 pandemic. Educ Inf Technol. 25, 5261-5280. https://doi.org/10.1007/s10639-020-10219-y

Al-Shboul, M., Rababah, O., Al-Saideh, M. I., Betawi, I., \& Jabbar, S. (2013). A Vision to Improve E-Learning at The University of Jordan. World Applied Sciences Journal, 21(6), 902-914.

Aung, T. N., \& Khaing, S. S. (2015). Challenges of implementing e-learning in developing countries: A review. International Conference on Genetic and Evolutionary Computing (pp. 405-411). Springer, Cham. https://doi.org/10.1007/978-3-319-23207-2_41

Azhari, F. A., \& Ming, L. C. (2015). Review of E-learning practice at the tertiary education level in Malaysia. Indian Journal of Pharmaceutical Education and Research, 49(4), 248-257. https://doi.org/10.5530/ijper.49.4.2

Bataineh, K. B., Atoum, M. S., Alsmadi, L. A., \& Shikhali, M. (2021). A Silver Lining of Coronavirus: Jordanian Universities Turn to Distance Education. International Journal of Information and Communication Technology Education, 17(2), 138-148. https://doi.org/10.4018/IJICTE.20210401.oa1

Dhawan, S. (2020). Online Learning: A Panacea in the Time of COVID-19 Crisis. Journal of Educational Technology Systems, 49(1), 5-22. https://doi.org/10.1177/0047239520934018

El-Mhouti A., Erradi M., \& Nasseh, A. (2018). Using cloud computing services in e-Learning process: Benefits and challenges. Educagtion and Information Technologies, 23(2), 893-909. https://doi.org/10.1007/s10639-017-9642-x

Fayyoumi, E., Idwan, S., AL-Sarayreh, K., \& Obeidallah, R. (2015). E-learning: challenges and ambitions at Hashemite University. International Journal of Innovation and Learning, 17(4), 470-485. https://doi.org/10.1504/IJIL.2015.069632

Hong, J. C., Tai, K. H., Hwang, M. Y., Kuo, Y. C., \& Chen, J. S. (2017). Internet cognitive failure relevant to users' satisfaction with content and interface design to reflect continuance intention to use a government E-learning system. Computers in Human Behavior, 66, 353-362. https://doi.org/10.1016/j.chb.2016.08.044

Hrastinski, S. (2008). The potential of synchronous communication to enhance participation in online discussions: A case study of two e-learning courses. Information \& Management, 45(7), 499-506. https://doi.org/10.1016/j.im.2008.07.005

Jethro O. O., Grace, A. M., \& Thomas, A. K. (2012). E-Learning and Its Effects on Teaching and Learning in a Global Age. International Journal of Academic Research in Business and Social Sciences, 2(1), 203-210.

Kenan, T., Pislaru, C., Othman, A., \& Elzawi, A. (2013). The social impact and cultural issues affecting the e-learning performance in Libyan higher education institutes. International Journal of Information Technology \& Computer Science, 12(1), 50-56.

Maabreh, K., \& Hanandeh, E. (2015). Evaluating and enhancing e-learning in Jordan. International Journal Technology Enhanced Learning, 7(2), 134-142. https://doi.org/10.1504/IJTEL.2015.072028

Raheem, B. R., \& Khan, M. A. (2020). The Role of E-learning in Covid-19 Crisis. International Journal of 
Creative Research Thoughts, 18(3), 3135-3138.

Raspopovic, M., Jankulovic, A., Runic, J., \& Lucic, V. (2014). Success factors for e-learning in a developing country: A case study of Serbia. The International Review of Research in Open and Distributed Learning, 15(3), 1-23. https://doi.org/10.19173/irrodl.v15i3.1586

Sekaran, U. (2003). Research Methods for Business: A Skill-Building Approach (4th ed.). John Wiley \& Sons, New York.

Shahzad, A., Hassan, R., Aremu, A. Y., Hussain, A., \& Lodhi, R. N. (2021). Effects of COVID-19 in E-learning on higher education institution students: the group comparison between male and female. Quality \& Quantity, 55, 805-826. https://doi.org/10.1007/s11135-020-01028-z.

Silverman, D. (2011). Qualitative Research (3rd ed.). Sage, UK, London.

Tarus, J. K., Gichoya, D., \& Muumbo, A. (2015). Challenges of implementing e-learning in Kenya: A case of Kenyan public universities. The International Review of Research in Open and Distance Learning, 16(1), 120-141. https://doi.org/10.19173/irrodl.v16i1.1816

Traxler, J. (2018). Distance learning: Predictions and possibilities. Education in Science, 8(35), 1-13. https://doi.org/10.3390/educsci8010035

Wang, J., Sun, Y. H., Fan, Z. P., \& Liu, Y. (2005). A collaborative e-learning system based on multi-agent. Lecture Notes in Computer Science, 3828, 455-463. Springer, Berlin, Heidelberg. https://doi.org/10.1007/11600930_45

\section{Copyrights}

Copyright for this article is retained by the author(s), with first publication rights granted to the journal.

This is an open-access article distributed under the terms and conditions of the Creative Commons Attribution license (http://creativecommons.org/licenses/by/4.0/). 